\title{
Multijurisdictional Industrial Parks and Revenue Sharing: An Application of Growth Pole Theory
}

\author{
G. Jason Jolley (Corresponding Author) \\ Voinovich School of Leadership and Public Affairs, Ohio University \\ Bldg 21-The Ridges, Athens, OH 45701, United States \\ Tel: 1-740-593-9797_E-mail: jolleyg1@ ohio.edu \\ Sharon R. Paynter \\ Department of Political Science, East Carolina University \\ Brewster A133, Greenville, North Carolina 27858, United States \\ Tel: 1-252-238-5580Ｅ-mail: paynters@ecu.edu
}

Received: May 09, 2013 Accepted: June 02, 2013 DOI: 10.5296/jpag.v3i2.3669

\begin{abstract}
Rural communities often lack the fiscal capacity to make the necessary investments to differentiate their industrial and technology parks in a crowded marketplace. This case study examines Triangle North, a multi-jurisdictional industrial/technology park in North Carolina. The study discusses the application of growth pole theory as the intellectual underpinnings of the joint park, its innovative financing and revenue sharing arrangement, and lessons learned from its implementation that can be applied to other locales.
\end{abstract}

Keywords: revenue sharing, growth pole, multijurisdictional industrial parks, rural development 


\section{Macrothink}

\section{Introduction}

Industrial parks, and more recently mixed-use, office, and research parks, are among the extant economic development assets marketed by local governments to recruit business and industry to an area. In the United States, industrial parks are structured in three ways: publicly owned; held under a public-private partnership arrangement; or privately owned. In many instances, even privately owned parks may be subsidized through public investment in infrastructure, such as transportation improvements or water and sewer extension. A vexing question faced by economic developers and local government officials is how to enhance the prominence of their industrial parks in an already crowded marketplace. This is particularly challenging when city or county governments lack the fiscal resources to invest in new facilities or infrastructure improvements at existing parks.

This case study discusses how rural counties in North Carolina addressed the challenge of developing a competitive industrial/technology park. The analysis begins with a discussion of entrepreneurship and growth pole theory. Next, the paper briefly reviews Research Triangle Park (RTP), a prominent growth pole in North Carolina. A case study is used to describe a unique approach utilized by four rural counties in the Research Triangle region of North Carolina to develop a joint industrial park venture based on an application of growth pole theory and a unique revenue sharing agreement among the local governments. The history of the park, its grounding in academic theory, and its development to date are described. The implementation strategy for the park has several shortcomings, including deviation from the original plan, which are highlighted as lessons learned.

\section{Entrepreneurship: Definitions and Benefits}

The idea of entrepreneurship is not a new one. Jean-Baptiste Say noted around 1800 that "the entrepreneur shifts economic resources out of an area of lower and into an area of higher productivity and greater yield" (Drucker, 1985: 21). Entrepreneurship has been defined in two distinct ways. In the first, it is cast as small firms who have low cost of entry into a market space, few barriers, and experience relatively few problems becoming active; while the contrasting view positions entrepreneurship as the formulation of a new economic enterprise (Malecki, 1997). In this latter perspective, used in the present analysis, economic development responses to market opportunities left vacant by existing enterprises are seen an innovations that spur economic growth. Regions experiencing high levels of entrepreneurial activity spur new activities, and in this case the capacity to innovate is critical (Malecki, 1997). 
Table 1. Factors that Affect Entrepreneurship

\begin{tabular}{|c|l|}
\hline 1. Capital availability & $\begin{array}{l}\text { 7. Networks of experienced } \\
\text { entrepreneurs }\end{array}$ \\
\hline 2. Technically skilled labor force & 8. Supplier access \\
\hline 3. Market/customer access & 9. Favorable government policies \\
\hline 4. Proximate universities & 10. Available land \\
\hline 5. Accessible transportation & 11. Social capital (receptivity by citizens) \\
\hline 6. Available support services & 12. Quality of life \\
\hline
\end{tabular}

Source: Bruno and Tybjee, 1982.

Malizia and Feezer (1999) build on these factors by noting that research and development strength, innovative business communication strategies, skilled labor force, and physical and social infrastructure to facilitate networking among key stakeholders are also key factors for successful entrepreneurial ventures.

\section{Growth Pole Theory and Revenue Sharing Innovation}

Growth pole theory originated with Perroux (1950) and is based on the premise that strategic investment in innovative or dynamic industries attracts additional industries using shared technologies (Goldstein and Luger, 1992). The propulsive industries or lead firms theoretically lead to a change in output in accompanying firms such as manufacturing (Thomas, 1975). Growth poles originally referred to this agglomeration or cluster of growth industries and their associated linkages in the economy whose economic output served to drive economic growth (World Bank, 2011). Overtime, growth pole theory has taken many different conceptions and definitions (World Bank, 2011). Growth poles are perceived as having a spatial or geographic component in regional development policy (the focus of this paper), and growth poles are used to describe cities or other areas where economic growth is concentrated (World Bank, 2011).

As it relates to this case study, in the Research Triangle region of North Carolina, Research Triangle Park, a major employment hub, may be perceived as a growth pole with the presence of many innovative industries whose activities directly and indirectly lead to broader regional economic growth and employment.

\section{Research Triangle Regional Partnership: A Case Study in Innovation}

Developed through a public-private partnership in the 1950s, the Research Triangle Park (RTP) is one of the most successful and transformational research parks in United States history. Strategically located between three major research universities, Duke University (in Durham County), North Carolina State University (in Wake County), and the University of North Carolina at Chapel Hill (in Orange County), 7,000 acre RTP campus is home to more 


\section{Macrothink}

Journal of Public Administration and Governance

ISSN 2161-7104

2013, Vol. 3, No. 2

than 170 companies employing 39,000 full time equivalent workers and 10,000 contract workers (http://www.rtp.org/about-rtp).

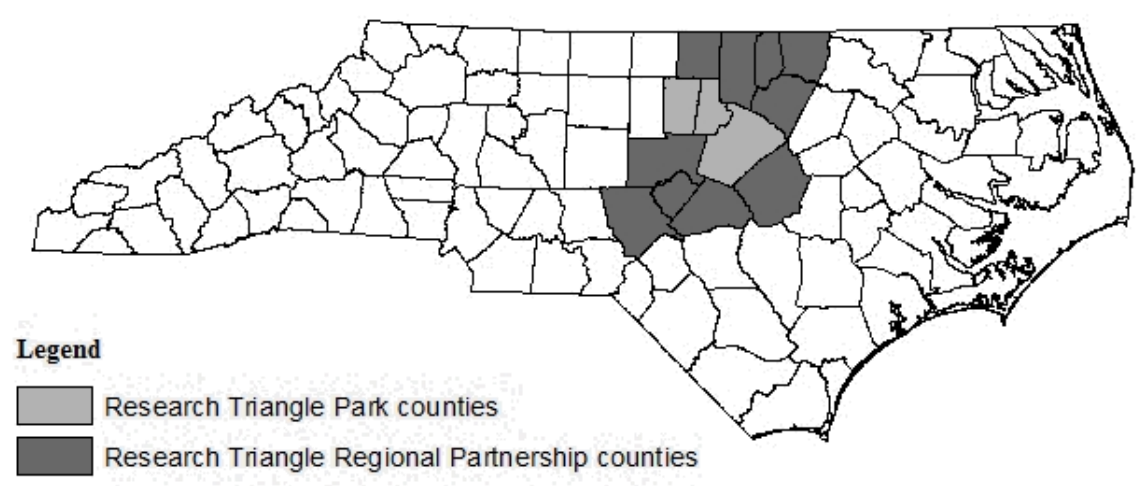

Source: Authors; Triangle North, 2012.

Figure 1. Research Triangle Park Region

The Research Triangle Regional Partnership (RTRP), shown in Figure 1, is a state mandated regional economic development agency representing 13 counties. The "Triangle" region in Wake, Durham, and Orange Counties (light gray in Figure 1) is located in the center of the partnership and is its core.

Table 2. Population (individuals), 1971-2010

\begin{tabular}{|l|l|l|l|l|}
\hline & $1971-1980$ & $1981-1990$ & $1991-2000$ & $2001-2010$ \\
\hline RTRP Counties & 458,656 & 618,870 & 969,387 & $1,302,381$ \\
\hline Triangle Counties & 397,049 & 449,370 & 580,435 & 719,567 \\
\hline
\end{tabular}

Source: U.S. Census, 1980; 1990; 2000; 2010.

Despite the success of RTP as a major employment hub, the economic development success found in the Triangle region has not reverberated as strongly across the surrounding region. A look at several economic indicators illustrates the dramatic differences in the counties within the Partnership. For example, as seen in Table 2, there are remarkable differences in growth across the two sub-regions of the Partnership. By 2010 the Triangle region tripled in size but growth across the remainder of the region has been much slower.

Table 3. Median Household Income (\$), 1980 to 2010, CPI adjusted to 2010 dollars.

\begin{tabular}{|l|l|l|l|l|}
\hline & 1980 & 1990 & 2000 & 2010 \\
\hline RTRP Counties & 34,431 & 40,972 & 47,449 & 44,233 \\
\hline Triangle Counties & 43,204 & 53,787 & 59,388 & 55,548 \\
\hline
\end{tabular}

Source: U.S. Census, 1980; 1990; 2000; American Community Survey, 2010. 
Household wealth, as demonstrated by median income and unemployment rates, is also very different in the Triangle versus the RTRP counties. While median household income has increased across the region (see Table 3), and both sub-regions saw about a $29 \%$ increase, higher wage jobs in the Triangle lead to more than $\$ 11,000$ per household compared to rural neighbors.

Table 4. Educational Attainment, 1980 to 2010.

\begin{tabular}{|l|l|l|l|l|}
\hline & 1980 & 1990 & 2000 & 2010 \\
\hline RTRP Counties & & & & \\
\hline Less than High School & 78,474 & 68,599 & 46,032 & 35,544 \\
\hline High School Graduates & 57,759 & 113,689 & 193,305 & 292,675 \\
\hline College Graduate or More & 9,926 & 22,047 & 36,428 & 64,959 \\
\hline Triangle Counties & & & & \\
\hline Less than High School & 58,085 & 44,574 & 28,305 & 63,137 \\
\hline High School Graduates & 110,333 & 212,336 & 369,413 & 833,282 \\
\hline College Graduate or More & 39,075 & 83,744 & 159,904 & 335,515 \\
\hline
\end{tabular}

Source: Federal Agency Data: Bureau of the Census - Census of Population and Housing.

Unemployment rates in the rural RTRP counties are on average more than twice those found in the Triangle counties over much of the past 40 years (Bureau of Labor Statistics, 2012). In the Triangle average unemployment rates hovered around 3.2\%, ranging from a high of 4.4 (1980) to a low of $2.6(1990,2000)$ (Bureau of Labor Statistics, 1980; 1990; 2000; 2010). In 2010 the rate climbed to about $8 \%$ across the three counties, a number still well below national averages. The story in the rural counties is much different. The lowest average unemployment rate across these counties was $4.2 \%$ in 1990 and $11.3 \%$ by 2010 .

There is a marked difference between the RTRP counties outside the Triangle and those within. The number of people shown in Table 4 who are 25 years or older and have 9 or fewer years of education in the ten RTRP counties was consistently higher than those in the Triangle until 2010.

Two factors may explain this. The number of people coming to the Triangle region has increased by at least $35 \%$ each decade since 1970 . The number of people in the ten rural counties has increased at a slower pace - about $22 \%$. Importantly, the number of people who have at least college degrees has grown steadily in the Triangle and across the rest of the region.

In some of the rural counties poverty is a serious challenge. For example, Vance and Warren 
counties, where poverty rates have averaged 21 and 26 percent respectively between 1980 and 2010 (U.S. Census) are persistently plagued with rampant unemployment, relatively few jobs outside the service industry, and few people with college degrees as compared to the Triangle region, or even among the other 8 counties in the rural part of the RTRP.

Yet, despite the economic success of the core counties and key cities of the Research Triangle Park region, Orange County (key city: Chapel Hill), Durham County (key city: Durham), and Wake County (key city: Raleigh), the prosperity and economic growth has failed reverberated to the counties in the periphery of the region. In the early 2000s, RTRP, in its role as the state mandated regional economic development entity, began exploring strategies to allow more rural counties in the region to share in the prosperity of RTP and the economic growth occurring in the region's core counties.

Professor Michael Luger at the University of North Carolina at Chapel Hill was contracted to examine strategies to address the economic disparity between the core counties and the rural counties in the region. Luger (2003) observed that RTP had fallen short of one of its original goals to attract R\&D facilities to RTP with an expectation that manufacturing facilities would follow. The founding premise was that companies would move manufacturing facilities to rural outskirts of the region to be in close proximity to the labs in RTP. Luger (2003) noted that this rarely occurred as, "it was merely a hope, not a plan of action" (1). Luger (2003) proposed to remedy this shortcoming by developing RTP-affiliated "mini-hubs" in rural areas of the RTP region. These mini-hubs would be enhanced sites for mid-tech businesses needing proximity to RTP, but requiring an abundance of less expensive land not available in RTP or the core counties.

Luger's (2003) mini-hub strategy was grounded in a regional development conception of growth pole theory. Luger's (2003) study considered RTP as the "maxi-hub" to which the mini-hub(s) would link via economic activity. He envisioned these mini-hubs serving as the growth pole outside of the urban center of RTP and cites this strategy as common practice in nonmetropolitan research parks (Luger and Goldstein, 1991). The mini-hubs are distinct from traditional industrial parks - mini-hubs require several hundred acres of contiguous land, hard infrastructure, and shell building with advanced specs such as lab space, conference facilities, and specialized infrastructure (Luger, 2003). Unlike a traditional industrial park, the type of tenants acceptable to the facility would be limited to those related to the region's identified industry clusters.

Over a decade ago, Levine (2002) estimated that there were 15,000 economic development organizations competing for roughly 1,500 major relocation or expansions each year in the United States, a 10 to 1 ratio. Given the rise in globalization and the Great Recession, it is reasonable to assume the ratio of economic development organization to major relocations in the U.S. has only increased. Such competition further highlights the need for economic development organizations to be able to differentiate their product in an increasingly competitive and global marketplace.

Given the necessary infrastructure to make these mini-hubs successful and differentiate them in the marketplace from other rural locations, it was unlikely that any of the rural counties in 
the RTP region could undertake the development of a mini-hub as a stand-alone county level project. In fact, having separate and competing rural industrial parks in adjacent counties can often be destructive within a shared labor shed. Pooling resources can allow for construction of better facilities that are more competitive in attracting relocating companies. Several strategies were proposed by Luger (2003) to remedy inter-county competition. He proposed joint financing and joint revenue sharing among rural counties through an interlocal agreement.

Furthermore, the level of distress among the rural counties is different. At the time of the original mini-hub concept, North Carolina divided its 100 counties into five tiers (20 in each tier) based on level of economic distress. Tier One counties were the most distressed and companies in these counties were eligible for higher levels of investment and job creation tax credits. Tier Five counties were the least distressed and companies in these counties were eligible for much lower levels of tax credits for similar activities.

Luger (2003) proposed that counties agreeing to the mini-hub concept should be allowed to share in the lowest tier status of the participating county, even if the jointly financed mini-hub happened to be located in a rural county with a higher tier status. For example, if two Tier Two counties and one Tier One county jointly funded and jointly shared in the tax revenues of a mini-hub, which was to be physically located one of the Tier Two counties, the companies in this mini-hub area would still receive favorable Tier One tax status on investment and job creation activities.

\section{Implementation in Practice}

While Luger's study suggested northern and southern rural mini-hubs, only the northern counties in the region considered the idea. In late 2002, five county managers in the northern region of the RTRP area met to consider the mini-hub concept (Triangle North, 2012). In 2003 an exploratory committee was formed to further develop potential plans (Triangle North, 2012). The Kerr-Tar Regional Council of Government stepped in to assist in facilitating the arrangement. In 2004, an implementation plan was written by Luger and his colleague Leslie Stewart (Stewart and Luger, 2004) for five counties in the northern region: Franklin, Granville, Person, Vance and Warren Counties. One of the central tenets of this implementation plan was utilized "a consensual process for selecting the best site for the hub" (Stewart and Luger, 2004: 9). Four of the counties, Franklin, Granville, Vance, and Warren, eventually agreed to proceed with the plan and signed an interlocal cooperation agreement in 2005 to form the Kerr-Tar Hub.

Several key steps occurred to facilitate the Kerr-Tar Hub. The North Carolina General Assembly, in 2005, lengthened the allowable terms for an interlocal agreement for a joint industrial park from 40 year to 99 years to accommodate the Kerr-Tar Hub (Morphis and Pearson, 2011). The interlocal agreement allowed the four counties to equally split cost of developing the hub and to share equally in the revenue (Morphis and Pearson, 2011). The North Carolina General Assembly also approved a \$4 million appropriate to assist with park development (Triangle North, 2012).

Additionally, a nonprofit, the Kerr-Tar Regional Economic Development Corporation was 


\section{Macrothink}

formed to manage the hub. In 2007, the State of North Carolina enacted Article 3J as a tax credit program. Article 3J replaced the sunsetting William S. Lee Act. While the William S. Lee Act divided the state's 100 counties into five tiers of economic distress, Article 3J reduced the tier designation to 3 tiers, Tier One (40 poorest), Tier Two (next 40 distressed) and Tier Three (least distressed). Two of the counties in the Kerr-Tar agreement were Tier One, one was Tier Two, and one was Tier Three under the new Article 3J designations (Morphis and Pearson, 2011). No matter where the mini-hub is located, companies in this hub receive Tier One status.

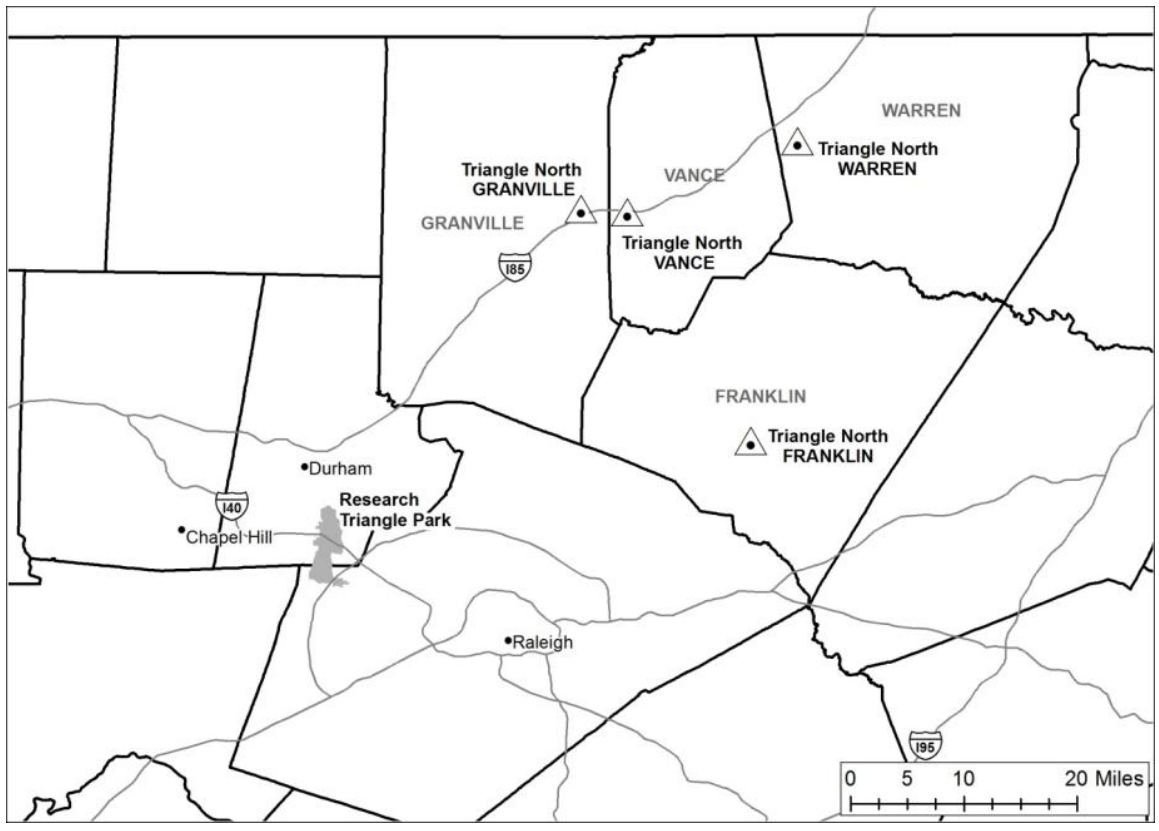

Source: Triangle North, 2012.

Figure 2. RTP and Triangle North sites

A substantial change did occur in the development of the mini-hub. While Luger's vision called for the development of the best site for the mini-hub, the counties involved eventually selected four separate sites under the mini-hub agreement. As the map demonstrates, these sites all share the tier status (Tier One) designation of the poorest counties, but are geographically dispersed. The Kerr-Tar Hub was also rebranded as Triangle North to demonstrate stronger tied to The Research Triangle Park (see Figure 2). 
Table 5. Selected Business Uses for Sites

\begin{tabular}{|l|l|l|l|l|}
\hline & Franklin & Granville & Vance & Warren \\
\hline Business Use & $\begin{array}{l}\text { High-tech and } \\
\text { aviation services }\end{array}$ & $\begin{array}{l}\text { Life sciences and } \\
\text { technology }\end{array}$ & $\begin{array}{l}\text { Mid-tech } \\
\text { businesses and } \\
\text { manufacturing }\end{array}$ & $\begin{array}{l}\text { Distribution, } \\
\text { logistics, and } \\
\text { manufacturing }\end{array}$ \\
\hline Acreage & 252 & 527 & 422 & 860 \\
\hline $\begin{array}{l}\text { Other } \\
\text { Information }\end{array}$ & $\begin{array}{l}\text { Two buildings: } \\
\text { One for office/light } \\
\text { industrial } \\
\text { One for light } \\
\text { industrial, } \\
\text { warehouse, or } \\
\text { distribution }\end{array}$ & $\begin{array}{l}\text { Adjacent } \\
\text { Community } \\
\text { College }\end{array}$ & $\begin{array}{l}\text { Across interstate } \\
\text { from } \\
\text { Vance-Granville } \\
\text { Community } \\
\text { College }\end{array}$ & $\begin{array}{l}\text { One of state's } \\
\text { largest sites and } \\
\text { marketed for } \\
\text { warehouse and } \\
\text { distribution } \\
\text { purposes }\end{array}$ \\
\hline
\end{tabular}

Source: Triangle North, 2012

The selected businesses uses for the sites (see Table 5) also vary and stray from the purposes outlined by Luger in his 2003 study. Luger (2003) wrote "whereas a 'typical' industrial park is happy to accept a wide range of tenants, including warehousing and distribution, and production of a wide variety of goods, mini-hubs would be developed around targeted industrial clusters, and would prefer business requiring semi-skilled and skilled labor" (18).

\section{Conclusion: Success and Lessons Learned}

North Carolina was severely impacted by the Great Recession. At the height of the recession, the state had lost over 300,000 jobs, including 100,000 in manufacturing. The state's unemployment rate has continued to lag the national average and remains among the highest in the country. Given the magnitude of the Great Recession, it is too early to judge the success or failure of the Triangle North venture. In 2011, U.S. Growers Direct (USGD) became the first company to announce location in Triangle North in the Franklin County. This company is building a $\$ 3.75$ million, 100,000 square foot facility. The company will collect agricultural products from farmers in the southeastern United States and ship these products globally. Initial plans call for 100 million pounds of flue-cured tobacco globally; employing 10-15 full time workers and 40 seasonal workers (Triangle Business Journal, 2011). This business, focused on distribution and warehousing, falls outside of the original parameters for a mid-tech oriented mini-hub as conceived by Luger.

Yet, if we measure Triangle North against the 12 factors for entrepreneurship the project has the potential for successful entrepreneurial activity. 
Table 6. Entrepreneurship Assessment

\begin{tabular}{|c|c|c|c|}
\hline Factor & $\begin{array}{l}\text { Triangle North } \\
\text { Counties }\end{array}$ & $\begin{array}{l}\text { RTRP } \\
\text { Counties }\end{array}$ & $\begin{array}{l}\text { Triangle } \\
\text { Counties }\end{array}$ \\
\hline Capital availability & & & $X$ \\
\hline Technically skilled labor force & & & $X$ \\
\hline Market/customer access & $X$ & $X$ & $X$ \\
\hline Proximate universities & $X$ & $\mathrm{X}$ & $X$ \\
\hline Accessible transportation & & & $X$ \\
\hline Available support services & $\mathrm{X}$ & $\mathrm{X}$ & $\mathrm{X}$ \\
\hline Networks of experienced entrepreneurs & $X$ & $X$ & $X$ \\
\hline Supplier accessibility & $X$ & $\mathrm{X}$ & $X$ \\
\hline Favorable governmental policies & $\mathrm{X}$ & $\mathrm{X}$ & $\mathrm{X}$ \\
\hline Available land & $\mathrm{X}$ & $\mathrm{X}$ & \\
\hline Social capital & $\mathrm{X}$ & $\mathrm{X}$ & $\mathrm{X}$ \\
\hline Quality of life & $X$ & $X$ & $X$ \\
\hline
\end{tabular}

Sources: Authors; Bruno and Tybjee, 1982.

In 2013 the Triangle Region has most of the resources needed for entrepreneurial success. With 40 years of business attraction, retention, and growth the area is solidified as an incubator for innovation but growth has lead to a rapid population expansion that results in crowded schools, roads, and neighborhoods. There are few large tracts of available land in the RTP region.

The rural counties in the RTRP have many of the factors associated with entrepreneurial success, including those in the Triangle North project. Land is plentiful in many of these areas, though the counties bordering the Triangle region are beginning to experience outflow as land and home values rise inside Wake, Durham, and Orange counties. Quality of life may be operationalized slightly differently in outlying regions where cultural opportunities may be fewer but recreational options are plentiful in places where state parks offer access to boating, fishing, and other activities on area lakes. The biggest challenges are finding capital, technically skilled workforces, and transportation. The easy access to RTP companies and entrepreneurs makes it possible to set up networks in places like Triangle North.

It is difficult to conduct a counterfactual analysis on the likely impact of alternative 
development scenarios, but an important unanswered question is whether the decision to build four separate parks undercuts the primary advantage of cost-sharing in the mini-hub concept. Building a research park with amenities and infrastructure that exceeded what these counties could finance on an individual basis was the central tenant of Luger's conception. Developing four separate parks under a shared revenue umbrella seems to undercut this competitive advantage.

Despite these shortcomings, the original conception of the mini-hubs does offer an important and innovative model for other rural communities to follow. Allowing governmental entities to share in the cost and revenues and leverage the economic tax benefits for the poorest locales allows government to avoid destructive competition associated with each entity building a competing industrial or research park in the same labor market.

\section{References}

Bruno, A.V. and Tybjee, T.T. (1982), "The Environment for Entrepreneurship" in C.A. Kent, D.L. Sexton and K.H. Vesper (eds.), Encyclopedia of Entrepreneurship, New Jersey, Prentice-Hall

Drucker, P.F. 1985. Innovation and Entrepreneurship. Harper and Row.

Goldstein, H.A. and Luger, M.I. 1992. "University-Based Research Parks as a Rural Development Strategy.” Policy Studies Journal 20(2): 249-263.

Levine T.M. 2002. "Six Revolutions in Economic Development Marketing." Economic Development Journal 1(1): 5-12.

Luger, M.I. 2003. The Feasibility of Mini-Hub Development in the Research Triangle Regional Partnership Region. Office of Economic Development, University of North Carolina at Chapel Hill.

Malecki, E.J. 1997. Technology and Economic Development: The Dynamics of Local,

Regional and National Competitiveness (2nd ed.). Essex, England: Addison Wesley Longman Limited.

Morphis, C. and Pearson, E. 2011. "Creating Economic Opportunity." Economic Development Journal 10(2): 28-35.

Perroux, F. 1950. "Economic Space, Theory, and Applications." Quarterly Journal of Economics LXIV: 89-104.

Research Triangle Park. 2012. “About Research Triangle Park.” Accessed November 20, 2012. http://www.rtp.org/about-rtp

Stewart, L.S. and Luger, M.I. 2004. Implementation Plan for a Mini-Hub in the Kerr-Tar Region. Office of Economic Development, University of North Carolina at Chapel Hill.

The World Bank. 2011. Multipolarity: The New Global Economy. The World Bank: Washington, D.C.

Thomas, M.D. 1975. "Growth Pole Theory, Technological Change, and Regional Growth." Papers in Regional Science 34(1): 3-25. 
Triangle Business Journal. 2011. "U.S. Growers Direct picks Franklin.” Triangle Business Journal April 5, 2011. Accessed November 20, 2012. http://www.bizjournals.com/triangle/news/2011/04/05/us-growers-direct-picks-franklin.html

Triangle North. 2012. Accessed November 20, 2012. http://www.trianglenorthnc.org/

U.S. Census Bureau. Decennial Census: 1970, 1980, 1990, 2000. American Community Survey, 2010.

U.S. Bureau of Labor Statistics: 1970, 1980, 1990, 2000, 2010.

\section{Copyright Disclaimer}

Copyright reserved by the author(s).

This article is an open-access article distributed under the terms and conditions of the Creative Commons Attribution license (http://creativecommons.org/licenses/by/3.0/). 